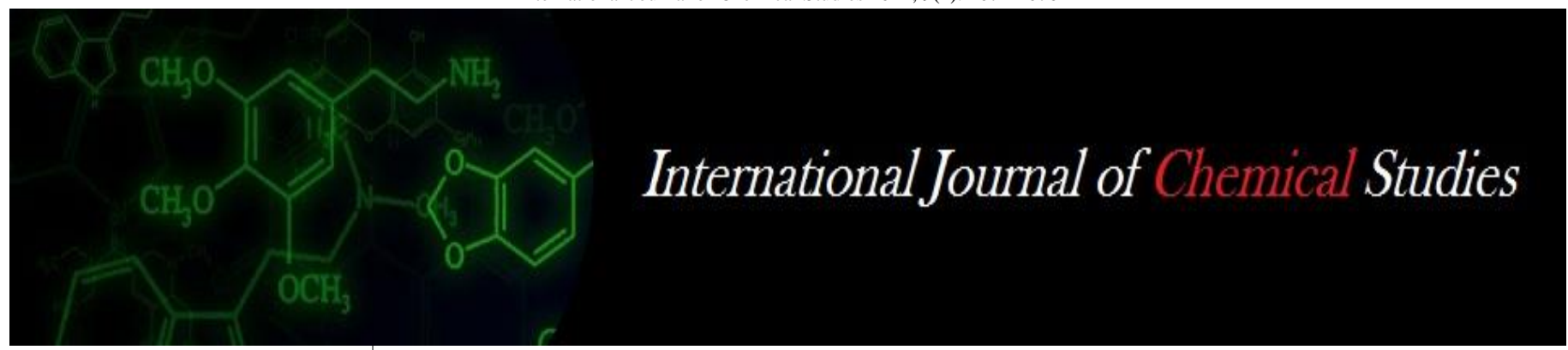

P-ISSN: 2349-8528

E-ISSN: 2321-4902

www.chemijournal.com

IJCS 2021; 9(1): 1071-1076

(C) 2021 IJCS

Received: 14-10-2020

Accepted: 15-12-2020

Amrutha S Ajayan

Research Scholar, Department of

Soil Science and Agricultural

Chemistry, College of

Agriculture, Vellayani, Kerala, India

Manorama Thampatti KC

Professor, Department of Soil

Science and Agricultural

Chemistry, College of

Agriculture, Vellayani, Kerala,

India

Corresponding Author:

Amrutha S Ajayan

Research Scholar, Department of

Soil Science and Agricultural

Chemistry, College of

Agriculture, Vellayani, Kerala,

India

\section{Boron dynamics in red loam soil amended with different organic fertilizers}

\author{
Amrutha S Ajayan and Manorama Thampatti KC
}

DOI: https://doi.org/10.22271/chemi.2021.v9.i1o.11368

\begin{abstract}
Boron is an essential micronutrient which is required in trace amount by the crop plants for their growth and development. There is a widespread deficiency of B in Indian soils and it has emerged as the second most deficient micronutrient after zinc. As its requirement is less, the deficiency can be corrected with the application of organic manures to a certain extent. The boron present in the soil exists in different chemical forms. The different fractions of B in the soil are readily soluble (Rs-B), specifically adsorbed (Spa-B), oxide bound (Ox-B), organically bound (Org-B) and residual B (Res-B). All these fractions together form the total B (T-B) content in the soil. As application of organic manures had a positive influence on the B availability, an incubation study was conducted for period of 24 weeks to analyze the release pattern of $\mathrm{B}$ and their dynamics in red loam soil amended with different organic fertilizers. The availability of B in the soil was mainly influenced by the dynamics of B fractions in the soil. Addition of organic amendments enhanced the readily available and specifically adsorbed B fractions in the soil and thereby increased B availability. The highest availability was from fortified thermochemical organic fertilizer (F-TOF) amended soil. It was mainly due to their higher B content than other organic fertilizers. The study of B dynamics in the soil provides a clear idea on its availability as well as the potential B reserve in the soil.
\end{abstract}

Keywords: Boron fractions, vermicompost, microbial compost, FYM, thermochemical organic fertilizer, boron dynamics, red loam soil

\section{Introduction}

Boron is one of the essential micronutrient required for the growth and development of crop plants. It is required for the reproductive functions of crop plants and its deficiency results in poor grain or fruit yield and production of seeds with inferior quality (Prasad et al., 2014) ${ }^{[20]}$. The intensive cultivation practices with the excess application of chemical fertilizers, overlooking the addition of organic manures have resulted in wide spread deficiency of micronutrients in Indian soils. Boron has emerged as the second most deficient micronutrient in the Indian soils after zinc (Ahmad et al., 2012) ${ }^{[1]}$. There is an acute deficiency of B in highly leached sandy soils, calcareous soil of Bihar and Tamil Nadu (Borkakati and Takkar, 2000; Alloway, 2008) [5, 2], red and laterite soils of Karnataka, Andrapradesh and Orissa (Singh, 2012) ${ }^{[25]}$ and in the soils of Kerala which are mainly derived from acidic igneous rocks (SSO, 2007) ${ }^{[26]}$. Boron has become an important yield limiting nutrient in the agricultural lands and its external application as fertilizers become prerequisite. As its requirement is less, the deficiency can be corrected with the application of organic manures to a certain extent.

The boron present in the soil exists in different chemical forms. The different fractions of B in the soil include readily soluble (Rs-B), specifically adsorbed (Spa-B), oxide bound (Ox-B), organically bound (Org-B) and residual B (Res-B). All these fractions together contribute for the total B (T-B) content in the soil. The dynamics of B in the soil is highly versatile and its availability depend on different factors such as soil type, amount of organic matter content, $\mathrm{pH}$, clay minerals, iron and aluminum oxides and calcium carbonate content (Padbhushan and Kumar, 2017) ${ }^{[18]}$.

As Kerala is concerned the soils are highly acidic, low in organic matter and predominant clay minerals are sesquioxides (oxides and hydroxides of $\mathrm{Fe}$ and $\mathrm{Al}$ ). All these factors restrict the $\mathrm{B}$ availability in Kerala soils. Also, the high amount of annual rainfall resulted in leaching loss of B due to their higher mobility in the soil (Jyolsna and Mathew, 2008) ${ }^{[16]}$. 
There is a widespread deficiency of B in Kerala soil. About 62 per cent of Kerala soils are deficient in boron (Anon. 2019) ${ }^{[3]}$. The readily soluble B and specifically adsorbed B are the two fraction of boron that is available for plant uptake (Padbhushan and Kumar, 2017) ${ }^{[18]}$. There are several reports on the positive correlation between the soil organic matter content and availability of B in the soil (Chang et al., 1983; Takkar et al., 1989; Shafiq et al., 2008) ${ }^{[6,28,23]}$. Jones (2003) ${ }^{[15]}$ reported organically bound $\mathrm{B}$ as the major $\mathrm{B}$ fraction in the cultivated soils to support plant growth. So application of organic manures can increase the availability of B in the soil. As application of organic manures had a positive influence on the B availability, an incubation study was conducted with different organic fertilizers such as FYM, ordinary compost (OC), vermicompost (VC), microbial compost (MC) unfortified (TOF) and fortified thermochemical (F-TOF) to analyze the release of $\mathrm{B}$ from different organic fertilizers amended to a red loam soil for period of 24 weeks. The thermo chemical organic fertilizer is an innovative technology of production of organic fertilizers from bio-waste by their thermo chemical decomposition (Sudarmaidevi et al., 2017) [27]. Here, the boron release pattern from different organic fertilizers and their transformation in the soil were studied. It is imperative to study the dynamics of $\mathrm{B}$ (different fractions of B) in the soil to get a clear idea on its availability as well as the potential $\mathrm{B}$ reserve in the soil.

\section{Materials and Methods}

Two kilogram of $2 \mathrm{~mm}$ sieved red loam soil was mixed with 50 grams of different organic fertilizers: FYM, ordinary compost (OC), vermicompost (VC), microbial compost (MC), and unfortified (TOF) and fortified (F-TOF) thermochemical organic fertilizers and incubated at field capacity for 24 weeks. Soil samples were taken at periodic intervals i.e. at 1 , $4,8,12,16,20$ and $24^{\text {th }}$ weeks of incubation and analyzed for their different fractions of boron using standard analytical methods (Hou et al., 1994) ${ }^{[10]}$. Readily soluble B (Rs-B) by $0.01 \mathrm{M} \mathrm{CaCl}_{2}$ extraction and colorimetric determination with azomethine $-\mathrm{H}$, Specifically adsorbed B (Spa-B) by $0.05 \mathrm{M}$ $\mathrm{KH}_{2} \mathrm{PO}_{4}$ extraction and colorimetric determination with azomethine $-\mathrm{H}$, Oxide bound $\mathrm{B}(\mathrm{Ox}-\mathrm{B})$ by extraction with $0.2 \mathrm{M} \mathrm{NH}_{4}$-oxalate ( $\mathrm{pH} 3.25$ ) and colorimetric determination with carmine dye, Organically bound $\mathrm{B}(\mathrm{Org}-\mathrm{B})$ by extraction with $0.02 \quad \mathrm{M} \quad \mathrm{HNO}_{3}+30 \% \quad \mathrm{H}_{2} \mathrm{O}_{2}$ and colorimetric determination with carmine dye, Total $\mathrm{B}$ by nitric-perchloric (9:4) acid digestion and colorimetric determination with azomethine $-\mathrm{H}$ and residual $\mathrm{B}$ was determined by subtracting all other boron fractions from the total B. Available boron in these soil samples were determined by hot water extraction followed by colorimetric determination with azomethine $-\mathrm{H}$ (Gupta, 1967) ${ }^{[9]}$.

The organic fertilizers used in the study were characterized for their boron content using standard analytical procedure i.e., by nitric-perchloric (9:4) acid digestion followed by colorimetric determination with azomethine $-\mathrm{H}$ (Roig et al., 1996) ${ }^{[22]}$.

\section{Results}

\section{Characterization of organic fertilizers}

The organic fertilizers used in the study such as FYM, ordinary compost (OC), vermicompost (VC), microbial compost (MC), unfortified (TOF) and fortified (F-TOF) thermochemical organic fertilizer were characterized for their boron content. The boron content in the organic fertilizer ranged from 17.60 to $46.40 \mathrm{mg} \mathrm{kg}^{-1}$. The highest boron content was with fortified thermochemical organic fertilizer (F-TOF) followed by vermicompost (VC) and microbial compost (MC). The lowest boron content was recorded by FYM. The higher boron content in the F-TOF was due to its fortification with external source of boron. Thermochemical organic fertilizer was produced by thermo-chemical digestion of biowaste as per the protocol of Sudarmaidevi et al., (2017) [27]. Unfortified thermochemical organic fertilizer (TOF) was low in its nutrient content, compared to the other conventional and non-conventional organic fertilizers (Sudarmaidevi et al., 2017; Jacob, 2018) ${ }^{[27,11]}$. Boron content in TOF was only 20 $\mathrm{mg} \mathrm{kg} \mathrm{kg}^{-1}$, even though substrates used for production of all these organic fertilizers were same, except FYM. Thus the TOF was fortified with external source for boron along with other macro and micronutrients. This has led to the higher boron content in the F-TOF.

\section{Fractions of boron in the soil Readily available boron}

Readily available B (Rs-B) is an important fraction as B availability is concerned. There was an increase in the readily available boron from first week onwards due to the application of organic fertilizers. It gradually increased up to $12^{\text {th }}$ week and slightly declined after wards. The higher value for Rs- B was recorded with F-TOF throughout the incubation period. It was mainly due their higher total boron content. It was followed by VC and OC. In control soil also there was increase in the Rs- B content up to $8^{\text {th }}$ week and later got stabilized around a constant value. The increase in the Rs- B in the treatment without organic fertilizers was due the mineralization process that had taken place in the soil under the given moisture (field capacity) and environment condition.

\section{Specifically adsorbed boron}

The pattern of release of specifically absorbed B (Spa-B) was same as that of Rs- B. It has also increased up to $12^{\text {th }}$ week due to addition of organic fertilizers and slightly declined afterwards. Throughout the incubation, the higher value for Spa-B was recorded with F-TOF due their higher boron content. It was followed by $\mathrm{VC}$ and $\mathrm{OC}$. In control soil also like Rs- B, concentration of Spa-B increased up to $8^{\text {th }}$ week and later got stabilized around constant value.

\section{Oxide bound boron}

Oxide bound boron $(\mathrm{Ox}-\mathrm{B})$ is the boron that are found in association with the oxides of $\mathrm{Al}$ and $\mathrm{Fe}$ in the soil. Red soils are rich in sesquioxide clay minerals which bound the B present in the soil. Throughout the incubation, oxide bound B was highest with F-TOF followed by VC and OC. In these treatments Ox-B increased gradually up to $16^{\text {th }}$ week and afterwards it had stabilized around a stable value. In the case of MC and TOF amended soil Ox-B increased up to $20^{\text {th }}$ week and stabilized after wards. In control the Ox-B stabilized after $4^{\text {th }}$ week.

\section{Organically bound B}

Organically bound B (Org-B) in the soil increased gradually up to $12^{\text {th }}$ week due to the addition of organic fertilizers and declined afterwards. Throughout the incubation highest Org-B was recorded with F-TOF followed by VC and OC. In control where there was no addition of organic fertilizer, the Org-B had almost a stabilized value throughout the incubation 


\section{Residual B}

Residual B (Res-B) in the soil indicates the reserve of boron in the soil. Like other B fractions, throughout the incubation the highest residual boron content was recorded with F-TOF followed VC and OC. Res-B content varied throughout the incubation with the changes that had occurred to the other fractions. However in control soil the Res-B did not altered much. It almost maintained stable value throughout incubation as the transformations in to other fractions were meager in control soil. Only a very small quantity of B reserve in the soil has got mineralized under given moisture and environment condition.

\section{Available boron in the soil}

The availability of B was highest from F-TOF amended soil followed by VC and MC. For these treatments the peak B availability was at $12^{\text {th }}$ week and it declined afterwards (Fig 1). But for MC and TOF amended soil, B availability increased consistently up to $20^{\text {th }}$ week and stabilized afterwards.

\section{Discussion}

There is a widespread deficiency of B in Kerala soils (Anon, 2019) ${ }^{[3]}$. The main factors which check B availability in Kerala soils are high soil acidity, low organic matter content and presence of sesquioxides clay minerals. As the B requirement of crop plants are less, the deficiency can be corrected with the application of organic manures to a certain extent. There is a sharp decline in the SOC content of the soil due to the climatic conditions (high temperature and heavy annual rainfall) and unscientific cultivation practices. The need of the hour is a noble organic fertilizer to replenish the depleting soil carbon pools and nutrient requirement of crop plants. F-TOF is gaining importance in the present scenario because the production process is very rapid and within 2 days the final organic fertilizer can be produced

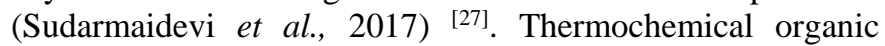
fertilizer had a higher TOC than other commonly used organic manures (Jacob, 2018; Ramesha, 2019) ${ }^{[11,21]}$ and it had a comparable effect when used as a substitute for organic manure in crop production ((Jayakrishna and Thampatti, 2016; Leno et al., $2016^{[12,17]}$. At the same time it did not interfere with the nutrients mineralization and their availability to the crop plants (Jacob, 2018) ${ }^{[11]}$. Thus thermochemical organic fertilizer has got a wide acceptance in Kerala. The higher boron content in the F-TOF resolves the boron deficiency and is an apt option for Kerala condition. Here the boron dynamics in the soil amended with F-TOF and TOF was compared with the other organic fertilizers which were commonly used.

The different fractions of boron in the soil were influenced by the application of organic fertilizers. Throughout the incubation the fractions were transforming among one another. The fractions such as readily available B, specifically adsorbed B, organically bound B increased up to $12^{\text {th }}$ week of incubation and then declined. Similarly oxide bound B increased up to $16^{\text {th }}$ week and then declined. The residual $\mathrm{B}$ declined up to $12^{\text {th }}$ week due to the application of organic fertilizers and started increasing from $16^{\text {th }}$ week onwards. Throughout the incubation for all the five fractions of $\mathrm{B}$, highest values were recorded with F-TOF. It was mainly due to the higher $\mathrm{B}$ content in F-TOF compared to the other organic fertilizers used. The boron content in the F-TOF increased due its fortification with borax.
Increase in the readily available B indicates the availability of $\mathrm{B}$ in the soil solution for crop uptake and it is controlled by the other fractions of B in the soil (Xu et al., 2001) ${ }^{[29]}$. This pool constitutes 1-2\% of total soil B (Padbhushan and Kumar 2017) ${ }^{[19]}$. In the incubation study under the application of organic fertilizers the readily available B increased up to $4 \%$. In the treatment without organic fertilizer the Rs-B ranged from 0.82 to $2.01 \%$. In the organic fertilizer added treatments it ranged from 1.02 to $4.01 \%$. The specifically adsorbed boron (Spa-B) is the fraction that are specifically adsorbed on to clay surfaces or associated with OM in soil (Jin et al., 1987) [13]. Addition of organic fertilizer directly influences and increase specifically adsorbed B fraction in the soil. This pool generally constitutes $0.01-0.61 \%$ of total soil $\mathrm{B}$ ( $\mathrm{Xu}$ et al. 2001) ${ }^{[29]}$. In the incubation study the treatment without organic fertilizers had specifically adsorbed B ranging from 1.23 to $2.10 \%$. In the organic fertilizer added treatment it increased and ranged from $1.45-6 \%$. The oxide bound boron $(\mathrm{Ox}-\mathrm{B})$ fraction is associated with oxides and hydroxides of $\mathrm{Fe}$ and Al. It is a less labile fraction of B and is usually available for crop uptake (Jin et al., 1988) ${ }^{[14]}$. This pool constitutes $<3 \%$ of total boron (T-B) (Hou et al. 1994) ${ }^{[10]}$. In the incubation study the treatment without organic fertilizers had oxide bound B ranging from 0.32 to $0.64 \%$. In the organic fertilizer added treatments it increased and ranged from 0.49 $2.59 \%$. In red loam soil, there is appreciable amount of oxides and hydroxides of $\mathrm{Fe}$ and $\mathrm{Al}$ and this had increased amount of oxide bound $\mathrm{B}$ fraction in the soil.

Organically bound B is the fraction of B associated with organic matter. This fraction constitutes $2-8 \%$ of total $\mathrm{B}$ (Padbhushan and Kumar 2017) ${ }^{[18]}$. In the incubation study the treatment without organic fertilizers had organically bound B ranging from 1.53 to $1.71 \%$. In all the organic fertilizer amended treatment there was a noticeable increase in the amount of organic bound B fraction with time and it has increased up to $12^{\text {th }}$ week of incubation and declined afterward gradually with the stabilization of organic matter. In the organic fertilizer added treatments it had ranged from 2.18 to $9.01 \%$.

Residual B is the fraction associated with primary and secondary minerals within the crystal structure and considered as the non-labile form of B (Shuman, 1985; Chao and Sanzolone 1989) ${ }^{[24,7]}$. So this fraction is totally unavailable for plant uptake. Residual B accounts for the major portion of total soil B and it is nearly about $87.4-99.7 \%$ of total B (Padbhushan and Kumar 2017) ${ }^{[18]}$. In the incubation study the treatment without organic fertilizers had residual bound B ranging from 94.02 to $95.82 \%$. In the organic fertilizer added treatments it had ranged from 79 to $94.67 \%$. The decrease in the fraction was due to the transformations to other fractions of boron.

During incubation, there was only a slight variation in residual $\mathrm{B}$ fraction in the soil due to the addition of organic fertilizers. This change occurred due to the slight eccentricity occurred to the equilibrium of different fractions of $\mathrm{B}$ in the soil with the addition of organic fertilizers. The residual $\mathrm{B}$ also includes $\mathrm{B}$ occluded in crystalline $\mathrm{Al}$ and $\mathrm{Fe}$ oxyhydroxides (Xu et al., 2001) ${ }^{[29]}$ and there exist a positive correlation between the amount of residual $\mathrm{B}$ and sesquioxide content of the soil (Datta et al., 2002) ${ }^{[8]}$. The slight variation in the fractions of residual $\mathrm{B}$ was occurred with the variation in the oxide bound B. There exist a highly positive correlation between the residual bound $\mathrm{B}$ and oxide bound $\mathrm{B}$ in the soil (Barman et al., 2008) ${ }^{[4]}$. When the equilibrium between the 
fractions gets disrupted, the system itself tries to re-establish it by various transformation reactions. In the end of the incubation, the highest residual B was recorded with F-TOF; it was due to the high boron content in the F-TOF which maintained a high $\mathrm{B}$ reserve after the establishment of equilibrium with the different fractions of $\mathrm{B}$ in the soil. At $24^{\text {th }}$ week the there was no significant difference between the residual $\mathrm{B}$ fractions of control and the organic fertilizer added treatment such as OC, VC and MC. It was because in control, there was only slight mineralization from B-reserve, while in organic fertilizers added treatments, there was contribution of B from organic fertilizers. So even though the available B increased, the B-reserve in the organic fertilizers added soil was maintained almost same as that in control soil. But in FYM and TOF amended soil, there was depletion in B-reserve of the soil. Because, the available pool of boron increased with addition of FYM and TOF. But the contribution from FYM and TOF to replenish the reserve pools in equilibrium was less. Thus the residual B first declined with the increase of other fraction and increased with the decline in the other fraction and equilibrium among the various fractions was maintained.

Availability of boron in the soil depend on several factors such as soil type, amount of organic matter, $\mathrm{pH}$, clay minerals, iron and aluminum oxides and calcium carbonate content. In the case of Kerala soil there is widespread deficiency of B in the cultivated land. The availability of B in Kerala soil was mainly restricted by the factors such low organic matter content, highly acidic $\mathrm{pH}$, leaching loss due to the heavy annual rainfall, fixation by sesquioxide clay minerals etc.

Availability of boron in the soil increased drastically during incubation in the treatments where organic fertilizers were added (Fig 1). With the addition of FYM, OC, VC and FTOF, the availability of boron gradually increased up to $12^{\text {th }}$ week and for MC and TOF increased up to $20^{\text {th }}$ week. It was mainly due to the increase in the readily available and specifically adsorbed B fractions in the soil. Later availability of B slightly declined due the decline in these B fractions. In the control soil, the availability slightly increased up to $8^{\text {th }}$ week due to mineralization from the soil when maintained at field capacity and declined later. It is the boron fractions such as readily available B and specifically adsorbed B contribute for the available of boron in the soil (Padbhushan and Kumar 2017) ${ }^{[18]}$. As there exist equilibrium among the different fractions of B, when the readily available B and specifically adsorbed B are depleted by crop uptake, the transformation reactions take place to replenish these fractions again $(\mathrm{Xu}$ et al., 2001) ${ }^{[29]}$.

Table 1: Boron content in different organic fertilizers

\begin{tabular}{|c|c|}
\hline Manure & B content $\mathbf{( \mathbf { m g ~ k g } ^ { - \mathbf { 1 } } )}$ \\
\hline FYM & 17.60 \\
\hline OC & 30.40 \\
\hline VC & 32.00 \\
\hline MC & 28.80 \\
\hline TOF & 20.80 \\
\hline F-TOF & 46.40 \\
\hline
\end{tabular}

Table 2: Readily available B in the soil at different periods of incubation

\begin{tabular}{|c|c|c|c|c|c|c|c|}
\hline \multirow{2}{*}{ Treatments } & \multicolumn{7}{|c|}{ Readily available $B\left(\mathrm{mg} \mathrm{kg}^{-1}\right)$} \\
\hline & $\mathbf{1}^{\text {st }}$ week & $4^{\text {th }}$ week & $8^{\text {th }}$ week & $12^{\text {th }}$ week & $16^{\text {th }}$ week & $20^{\text {th }}$ week & $24^{\text {th }}$ week \\
\hline T1 Control & $0.036^{\mathrm{f}}$ & $0.056^{\mathrm{f}}$ & $0.088^{\mathrm{d}}$ & $0.078^{\mathrm{d}}$ & $0.076^{\mathrm{c}}$ & $0.078^{\mathrm{e}}$ & $0.074^{\mathrm{d}}$ \\
\hline T2 Soil+FYM & $0.049^{\mathrm{d}}$ & $0.130^{\mathrm{e}}$ & $0.156^{\mathrm{c}}$ & $0.193^{\mathrm{c}}$ & $0.188^{b}$ & $0.183^{\mathrm{cd}}$ & $0.180^{\mathrm{c}}$ \\
\hline T3 Soil+OC & $0.054^{\mathrm{c}}$ & $0.149^{b}$ & $0.186^{\mathrm{a}}$ & $0.206^{b}$ & $0.200^{\mathrm{ab}}$ & $0.193^{b}$ & $0.190^{b}$ \\
\hline T4 Soil+VC & $0.059^{b}$ & $0.151^{\mathrm{b}}$ & $0.188^{\mathrm{a}}$ & $0.207^{\mathrm{b}}$ & $0.200^{\mathrm{ab}}$ & $0.195^{b}$ & $0.191^{b}$ \\
\hline T5 Soil+MC & $0.053^{\mathrm{c}}$ & $0.143^{\mathrm{c}}$ & $0.179^{\mathrm{ab}}$ & $0.204^{b}$ & $0.195^{\mathrm{b}}$ & $0.189^{\mathrm{bc}}$ & $0.186^{\mathrm{b}}$ \\
\hline T6 Soil+TOF & $0.047^{\mathrm{e}}$ & $0.139^{\mathrm{d}}$ & $0.171^{\mathrm{b}}$ & $0.196^{c}$ & $0.187^{b}$ & $0.181^{\mathrm{d}}$ & $0.179^{c}$ \\
\hline T7 Soil+F-TOF & $0.090^{\mathrm{a}}$ & $0.156^{\mathrm{a}}$ & $0.190^{\mathrm{a}}$ & $0.222^{\mathrm{a}}$ & $0.217^{\mathrm{a}}$ & $0.212^{\mathrm{a}}$ & $0.205^{\mathrm{a}}$ \\
\hline S.Em \pm & 0.0007 & 0.0010 & 0.0050 & 0.0017 & 0.0057 & 0.0023 & 0.0233 \\
\hline C.D. (0.05) & 0.002 & 0.003 & 0.015 & 0.005 & 0.017 & 0.007 & 0.005 \\
\hline
\end{tabular}

Table 3: Specifically adsorbed B in the soil at different periods of incubation

\begin{tabular}{|c|c|c|c|c|c|c|c|}
\hline \multirow{2}{*}{ Treatments } & \multicolumn{7}{|c|}{ Specifically adsorbed $\mathrm{B}\left(\mathrm{mg} \mathrm{kg}^{-1}\right)$} \\
\hline & $1^{\text {st }}$ week & $4^{\text {th }}$ week & $8^{\text {th }}$ week & $12^{\text {th }}$ week & $16^{\text {th }}$ week & $20^{\text {th }}$ week & $24^{\text {th }}$ week \\
\hline T1 Control & $0.054^{\mathrm{d}}$ & $0.066^{\mathrm{g}}$ & $0.091^{\mathrm{e}}$ & $0.088^{\mathrm{e}}$ & $0.092^{\mathrm{e}}$ & $0.082^{\mathrm{d}}$ & $0.081^{\mathrm{g}}$ \\
\hline T2 Soil+FYM & $0.073^{\mathrm{c}}$ & $0.195^{\mathrm{f}}$ & $0.235^{\mathrm{d}}$ & $0.289^{\mathrm{d}}$ & $0.282^{\mathrm{d}}$ & $0.274^{\mathrm{c}}$ & $0.270^{\mathrm{e}}$ \\
\hline T3 Soil+OC & $0.081^{\mathrm{b}}$ & $0.223^{\mathrm{c}}$ & $0.278^{\mathrm{a}}$ & $0.308^{\mathrm{bc}}$ & $0.300^{\mathrm{b}}$ & $0.289^{b}$ & $0.284^{c}$ \\
\hline T4 Soil+VC & $0.089^{\mathrm{a}}$ & $0.226^{\mathrm{b}}$ & $0.281^{\mathrm{a}}$ & $0.311^{\mathrm{b}}$ & $0.299^{\mathrm{b}}$ & $0.292^{b}$ & $0.286^{\mathrm{b}}$ \\
\hline T5 Soil+MC & $0.080^{\mathrm{b}}$ & $0.215^{\mathrm{d}}$ & $0.268^{b}$ & $0.306^{\mathrm{bc}}$ & $0.292^{\mathrm{c}}$ & $0.284^{\text {bc }}$ & $0.279^{\mathrm{d}}$ \\
\hline T6 Soil+TOF & $0.071^{\mathrm{c}}$ & $0.208^{\mathrm{e}}$ & $0.257^{\mathrm{c}}$ & $0.294^{\mathrm{cd}}$ & $0.280^{\mathrm{d}}$ & $0.272^{\mathrm{c}}$ & $0.268^{\mathrm{f}}$ \\
\hline T7 Soil+F-TOF & $0.092^{\mathrm{a}}$ & $0.234^{\mathrm{a}}$ & $0.284^{\mathrm{a}}$ & $0.332^{\mathrm{a}}$ & $0.325^{\mathrm{a}}$ & $0.318^{\mathrm{a}}$ & $0.307^{\mathrm{a}}$ \\
\hline S.Em \pm & 0.0023 & 0.0007 & 0.0023 & 0.0050 & 0.0007 & 0.0040 & 0.0020 \\
\hline C.D. $(0.05)$ & 0.007 & 0.002 & 0.007 & 0.015 & 0.002 & 0.012 & 0.002 \\
\hline
\end{tabular}

Table 4: Oxide bound B in the soil at different periods of incubation

\begin{tabular}{|c|c|c|c|c|c|c|c|}
\hline \multirow{2}{*}{ Treatments } & \multicolumn{7}{|c|}{ Oxide bound B ( $\left.\mathrm{mg} \mathrm{kg}^{-1}\right)$} \\
\hline & 1 $^{\text {st }}$ week & $4^{\text {th }}$ week & $8^{\text {th }}$ week & $12^{\text {th }}$ week & $16^{\text {th }}$ week & $20^{\text {th }}$ week & $24^{\text {th }}$ week \\
\hline T1 Control & $0.018^{\mathrm{d}}$ & $0.028^{b}$ & $0.014^{b}$ & $0.018^{\mathrm{e}}$ & $0.015^{\mathrm{e}}$ & $0.014^{\mathrm{e}}$ & $0.014^{\mathrm{d}}$ \\
\hline T2 Soil+FYM & $0.024^{\mathrm{c}}$ & $0.065^{\mathrm{g}}$ & $0.078^{\mathrm{e}}$ & $0.096^{\mathrm{d}}$ & $0.098^{\mathrm{d}}$ & $0.094^{\mathrm{d}}$ & $0.090^{c}$ \\
\hline T3 Soil+OC & $0.027^{\mathrm{b}}$ & $0.074^{\mathrm{d}}$ & $0.093^{b}$ & $0.103^{\text {cd }}$ & $0.11^{\mathrm{c}}$ & $0.096^{c}$ & $0.095^{\mathrm{bc}}$ \\
\hline T4 Soil+VC & $0.030^{b}$ & $0.075^{c}$ & $0.094^{b}$ & $0.104^{b c}$ & $0.13^{c}$ & $0.097^{c}$ & $0.095^{\mathrm{bc}}$ \\
\hline T5 Soil+MC & $0.027^{\mathrm{b}}$ & $0.072^{\mathrm{e}}$ & $0.089^{\mathrm{c}}$ & $0.102^{\text {cd }}$ & $0.107^{\mathrm{cd}}$ & $0.109^{c}$ & $0.093^{c}$ \\
\hline T6 Soil+TOF & $0.024^{\mathrm{c}}$ & $0.069^{f}$ & $0.086^{d}$ & $0.09^{\mathrm{cd}}$ & $0.093^{\mathrm{d}}$ & $0.097^{\mathrm{d}}$ & $0.089^{c}$ \\
\hline
\end{tabular}




\begin{tabular}{|c|c|c|c|c|c|c|c|}
\hline T7 Soil+F-TOF & $0.036^{\mathrm{a}}$ & $0.078^{\mathrm{a}}$ & $0.095^{\mathrm{a}}$ & $0.108^{\mathrm{a}}$ & $0.111^{\mathrm{a}}$ & $0.106^{\mathrm{a}}$ & $0.102^{\mathrm{a}}$ \\
\hline SEm \pm & 0.0020 & 0.0003 & 0.0010 & 0.0023 & 0.0017 & 0.0010 & 0.0023 \\
\hline C.D. (0.05) & 0.005 & 0.001 & 0.003 & 0.007 & 0.005 & 0.003 & 0.008 \\
\hline
\end{tabular}

Table 5: Organically bound B in the soil at different periods of incubation

\begin{tabular}{|c|c|c|c|c|c|c|c|}
\hline \multirow{2}{*}{ Treatments } & \multicolumn{7}{|c|}{ Organically bound B $\left(\mathrm{mg} \mathrm{kg}^{-1}\right)$} \\
\hline & $1^{\text {st }}$ week & $4^{\text {th }}$ week & $8^{\text {th }}$ week & $12^{\text {th }}$ week & $16^{\text {th }}$ week & $20^{\text {th }}$ week & $24^{\text {th }}$ week \\
\hline T1 Control & $0.075^{\mathrm{g}}$ & $0.070^{\mathrm{f}}$ & $0.069^{g}$ & $0.068^{f}$ & $0.068^{f}$ & $0.068^{\mathrm{e}}$ & $0.067^{\mathrm{d}}$ \\
\hline T2 Soil+FYM & $0.110^{\mathrm{e}}$ & $0.292^{\mathrm{fe}}$ & $0.352^{f}$ & $0.434 \mathrm{e}$ & $0.423^{\mathrm{d}}$ & $0.411^{\mathrm{d}}$ & $0.405^{c}$ \\
\hline T3 Soil+OC & $0.122^{c}$ & $0.334^{\mathrm{bc}}$ & $0.417^{\mathrm{c}}$ & $0.463^{\mathrm{bc}}$ & $0.450^{\mathrm{b}}$ & $0.433^{\mathrm{b}}$ & $0.427^{\mathrm{b}}$ \\
\hline T4 Soil+VC & $0.133^{\mathrm{b}}$ & $0.339^{\mathrm{ab}}$ & $0.422^{\mathrm{b}}$ & $0.466^{\mathrm{b}}$ & $0.449^{b}$ & $0.438^{\mathrm{b}}$ & $0.430^{\mathrm{b}}$ \\
\hline T5 S oil+MC & $0.120^{\mathrm{d}}$ & $0.322^{\mathrm{cd}}$ & $0.403^{\mathrm{d}}$ & $0.459^{\mathrm{c}}$ & $0.438^{c}$ & $0.426^{\mathrm{c}}$ & $0.419^{\mathrm{b}}$ \\
\hline T6 Soil+TOF & $0.107^{f}$ & $0.313^{\mathrm{d}}$ & $0.385^{\mathrm{e}}$ & $0.441^{d}$ & $0.420^{\mathrm{e}}$ & $0.407^{\mathrm{d}}$ & $0.403^{c}$ \\
\hline T7 Soil+F-TOF & $0.137^{\mathrm{a}}$ & $0.351^{\mathrm{a}}$ & $0.427^{\mathrm{a}}$ & $0.499^{a}$ & $0.487^{\mathrm{a}}$ & $0.477^{\mathrm{a}}$ & $0.461^{\mathrm{a}}$ \\
\hline SEm \pm & 0.0007 & 0.0050 & 0.0017 & 0.0023 & 0.0007 & 0.0023 & 0.0023 \\
\hline C.D. $(0.05)$ & 0.002 & 0.015 & 0.005 & 0.007 & 0.002 & 0.007 & 0.012 \\
\hline
\end{tabular}

Table 6: Residual B in the soil at different periods of incubation

\begin{tabular}{|c|c|c|c|c|c|c|c|}
\hline \multirow{2}{*}{ Treatments } & \multicolumn{7}{|c|}{ Residual B ( $\left.\mathrm{mg} \mathrm{kg}^{-1}\right)$} \\
\hline & $1^{\text {st }}$ week & $4^{\text {th }}$ week & $8^{\text {th }}$ week & $12^{\text {th }}$ week & $16^{\text {th }}$ week & $20^{\text {th }}$ week & $24^{\text {th }}$ week \\
\hline T1 Control & $4.197^{\mathrm{e}}$ & $4.160^{f}$ & $4.118^{\mathrm{d}}$ & $4.128^{b}$ & $4.129^{b}$ & $4.138^{b}$ & $4.144^{\mathrm{b}}$ \\
\hline T2 Soil+FYM & $4.563^{\mathrm{d}}$ & $4.139^{\mathrm{e}}$ & $3.999^{\mathrm{f}}$ & $3.808^{\mathrm{g}}$ & $3.833^{\mathrm{d}}$ & $3.862^{\mathrm{d}}$ & $3.876^{\mathrm{c}}$ \\
\hline T3 Soil+OC & $4.855^{\mathrm{b}}$ & $4.360^{\mathrm{bc}}$ & $4.166^{c}$ & $4.061^{\mathrm{d}}$ & $4.091^{\mathrm{b}}$ & $4.129^{b}$ & $4.145^{b}$ \\
\hline T4 Soil+VC & $4.870^{\mathrm{b}}$ & $4.389^{b}$ & $4.195^{b}$ & $4.092^{\mathrm{c}}$ & $4.133^{b}$ & $4.159^{b}$ & $4.178^{b}$ \\
\hline T5 Soil+MC & $4.821^{\mathrm{b}}$ & $4.348^{c}$ & $4.161^{\mathrm{c}}$ & $4.029^{\mathrm{e}}$ & $4.079^{b}$ & $4.106^{b}$ & $4.122^{b}$ \\
\hline T6 Soil+TOF & $4.651^{\mathrm{c}}$ & $4.171^{\mathrm{d}}$ & $4.002^{\mathrm{e}}$ & $3.871^{\mathrm{f}}$ & $3.921^{\mathrm{c}}$ & $3.950^{\mathrm{c}}$ & $3.961^{\mathrm{c}}$ \\
\hline T7 Soil+F-TOF & $5.185^{\mathrm{a}}$ & $4.722^{\mathrm{a}}$ & $4.545^{\mathrm{a}}$ & $4.377^{\mathrm{a}}$ & $4.403^{\mathrm{a}}$ & $4.428^{\mathrm{a}}$ & $4.464^{\mathrm{a}}$ \\
\hline $\mathrm{SEm} \pm$ & 0.0183 & 0.0100 & 0.0050 & 0.0023 & 0.0283 & 0.0233 & 0.0050 \\
\hline C.D. (0.05) & 0.055 & 0.030 & 0.015 & 0.007 & 0.085 & 0.070 & 0.10 \\
\hline
\end{tabular}

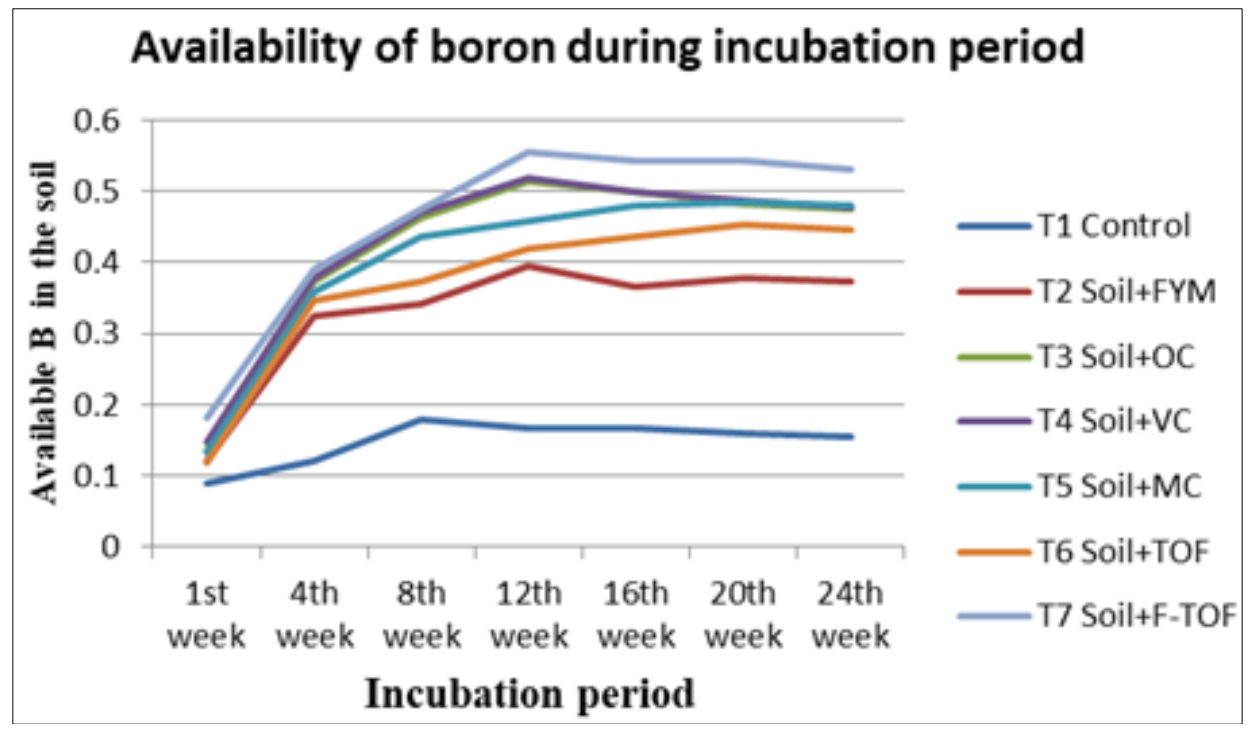

Fig 1: Availability of Boron during the incubation period

\section{Conclusion}

The dynamics of $\mathrm{B}$ in the soil is highly versatile and its availability depend on different factors such as soil type, amount of organic matter content, $\mathrm{pH}$, clay minerals, iron and aluminum oxides content etc. In the study, addition of different organic fertilizers has increased the availability of boron in the soil. With the addition of FYM, OC, VC and FTOF, the availability of boron gradually increased up to $12^{\text {th }}$ week and for MC and TOF increased up to $20^{\text {th }}$ week. Later availability of B slightly declined. The highest availability of B was observed with F-TOF amended soil followed by vermicompost. The availability of B in the soil was mainly influenced by the dynamics of B fractions in the soil. Addition of organic amendments enhanced the readily available and specifically adsorbed B fractions in the soil and thereby increased B availability. So the study on different fractions of boron in the soil provides information about the total boron reserve in the soil as well as the portion of $\mathrm{B}$ that become available to the crop plants.

\section{Acknowledgements}

The authors gratefully acknowledge the financial support provided by Department of Science and Technology (DST), Ministry of Science and Technology, Government of India for conduct of the research work.

\section{Reference}

1. Ahmad W, Zia MH, Malhi, SS, Niaz, A, Saifullah. Boron deficiency in soils and crops: A review. In: Crop Plant (Goyal, A., ed.) 2012. doi:10.5772/36702. 
2. Alloway BJ (ed.). Micronutrient Deficiencies in Global Crop Production (BJ. Alloway ed.), Springer, Dordrecht 2008,48-127.

3. Anonymous. Kerala Soil Information System-IIITM-K, Government of Kerala, Kerala 2019,1p.

4. Barman P, Sen A, Phonglosa A, Bhattacharyya K. Depth wise distribution of boron in some soils of red and laterite zone of West Bengal, India. Int. J Curr. Microbiol. App. Sci 2017;6(12):4126-4137. doi: https://doi.org/10.20546/ijcmas.2017.612.474

5. Borkakati K, Takkar PN. Forms of boron in acid alluvial and lateritic soils in relation to ecosystem and rainfall distribution. (In) Proceedings of the International Conference on Managing Resources for Sustainable Agricultural Production in the 21st Century. Better Crops 2000;2:127-28.

6. Chang SS, Hu NH, Chen CC, Chu TF. Diagnosis criteria of boron deficiency in papaya and the soil boron status of Taitung area (Taiwan). Chinese J. Soil Sci 1983;32:23852.

7. Chao TT, Sanzolone RF. Fractionation of soil selenium by sequential partial dissolution. Soil Sci. Soc. Am. J 1989;53:385-392.

8. Datta SP, Rattan RK, Kandregula S, Datta SC. Fractionation and colorimetric determination of boron in soils. J. Plant Nutri. Soil Sci 2002;165:179-184.

9. Gupta UC. A simplified method for determining hot water soluble boron in podzol soils. Soil Sci 1967;103(6):424-428.

10. Hou J, Evans LJ, Spiers GA. Chemical fractionation of soil boron: 1. Method development. Can. J. Soil. Sci 2013,485-491.

11. Jacob G. Rhizosphere priming effects of conventional and non-conventional organic manures on $\mathrm{C}$ and $\mathrm{N}$ dynamics. M.Sc. (Ag) thesis, Kerala Agricultural University, Thrissur 2018,156p

12. Jayakrishna J. Evaluation of thermochemical digest of degradable waste for container cultivation of chilli. M.Sc. (Ag) thesis, Kerala Agricultural University, Thrissur 2017,123p.

13. Jin JY, Martens DC, Zelazny LW. Plant availability of applied and native boron in soils with diverse properties. Plant Soil 1988;105:127-132.

14. Jin J, Martens DC, Zelazny LW. Distribution and plant availability of soil; boron fractions. Soil Sci. Soc. Am. J 1987;51:1228-1231.

15. Jones JB. Plant mineral nutrition. (In) Agronomic handbook: Management of crops, soils and their fertility, CRC Press, Boca Raton, FL, U.S.A 2003,325p.

16. Jyolsna VK, Mathew U. Boron nutrition of tomato (Lycopersicon esculentum L.) grown in the laterite soils of southern Kerala. J. Trop. Agric 2008;46(1-2):73-75.

17. Leno N, Sudharmaidevi CR, Meera AV. Fertility evaluation and manurial effect of organic manure produced from degradable solid waste by rapid conversion technology. Adv. Life Sci 2016;5:443-4436.

18. Padbhushan R, Kumar D. Fractions of soil boron: a review. J. Agri. Sci 2017,1-10. doi:10.1017/S0021859617000181

19. Padbhushan R, Mandal J, Kumar S, Kumar A. Chemical fractions and response of cauliflower (Brassica oleracea var. botrytis) to soil applied boron. J. Plant Nutr 2019,110. doi:10.1080/01904167.2019.1567770.
20. Prasad R, Kumar D, Shivay YS, Rana DS. Boron in Indian agriculture $-\mathrm{a}$ review. Indian J. Agron 2014;59(4):511-517.

21. Ramesha GK. Root phenomics and soil biological activity in response to thermochemical organic fertilizer application. M.Sc. (Ag) thesis, Kerala Agricultural University, Thrissur, 2019,140p

22. Roig A, Lax A, Costa F, Cegarra J, Hernandez T. The influence of organic materials on the physical and physico-chemical properties of soil. Agric. Medit 1996;117:309-318.

23. Shafiq M, Ranjha AM, Yaseen M, Mehdi, SM, Hannan A. Comparison of Freundlich and Langmuir adsorption equations for boron adsorption on calcareous soils. J. Agricultural Res 2008;46:141-48.

24. Shuman LM. Fractionation method for soil microelements. Soil Sci 1985;140:11-22.

25. Singh MV. Spread of micro-nutrient deficiencies specially boron in India and response of field crops. Brain storming workshop on soil test based nutrients including boron and other micro nutrients. Organized by ICRISAT - Agriculture Directorate, Karnataka -Rio Tinto India at Bengaluru, India 2012.

26. SSO, Benchmark Soils of Kerala. Soil Survey Organization, Agriculture (SC Unit) Department, Govt. of Kerala, Thiruvananthapuram 2007,623p

27. Sudharmaidevi CR, Thampatti KCM, Saifudeen N. Rapid production of organic fertilizer from degradable waste by thermochemical processing. Int. J. Recycl. Org. Waste Agric 2017;6:1-11.

28. Takkar PN, Chibba IM, Mehta SK. Twenty years of coordinated research on micronutrient in soils and plants. Bulletin 314. Indian Institute of Soil Science, Bhopal, India 1989,81p.

29. Xu JM, Wang K, Bell, RW, Yang YA, Huang LB. Soil boron fractions and their relationship to soil properties. Soil Sci. Soc. Am. J 2001;65:133-138. 